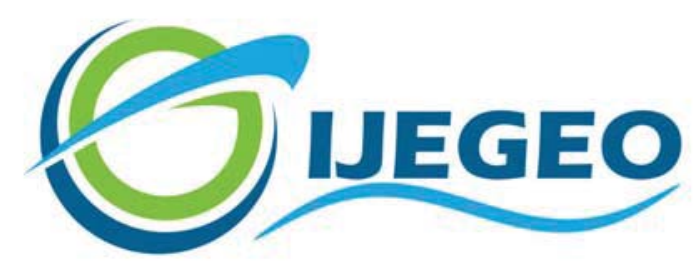

International Journal of Environment and Geoinformatics (IJEGEO) is an international, multidisciplinary, peer reviewed, open access journal.

\title{
Analysis of Optimum Growth Stages for Winter Crop Separability using Multi-Temporal NDVI Profiles in Vijapur Taluka, Gujarat State-India
}

\author{
Jayraj B. PANCHAN., Shital H. SHUKLA., Manik H. KALUBARME
}

\author{
Chief in Editor \\ Prof. Dr. Cem Gazioğlu \\ Co-Editors \\ Prof. Dr. Dursun Zafer Şeker, Prof. Dr. Şinasi Kaya, \\ Prof. Dr. Ayşegül Tanık and Assist. Prof. Dr. Volkan Demir
}

Editorial Committee (June 2021)

\begin{abstract}
Assoc. Prof. Dr. Abdullah Aksu (TR), Assit. Prof. Dr. Uğur Algancı (TR), Prof. Dr. Bedri Alpar (TR), Assoc. Prof. Dr. Aslı Aslan (US), Prof. Dr. Levent Bat (TR), Prof. Dr. Paul Bates (UK), İrşad Bayırhan (TR), Prof. Dr. Bülent Bayram (TR), Prof. Dr. Luis M. Botana (ES), Prof. Dr. Nuray Çağlar (TR), Prof. Dr. Sukanta Dash (IN), Dr. Soofia T. Elias (UK), Prof. Dr. A. Evren Erginal (TR), Assoc. Prof. Dr. Cüneyt Erenoğlu (TR), Dr. Dieter Fritsch (DE), Prof. Dr. Çiğgem Göksel (TR), Prof.Dr. Lena Halounova (CZ), Prof. Dr. Manik Kalubarme (IN), Dr. Hakan Kaya (TR), Assist. Prof. Dr. Serkan Kükrer (TR), Assoc. Prof. Dr. Maged Marghany (MY), Prof. Dr. Michael Meadows (ZA), Prof. Dr. Nebiye Musaoğlu (TR), Prof. Dr. Masafumi Nakagawa (JP), Prof. Dr. Hasan Özdemir (TR), Prof. Dr. Chryssy Potsiou (GR), Prof. Dr. Erol Sarı (TR), Prof. Dr. Maria Paradiso (IT), Prof. Dr. Petros Patias (GR), Prof. Dr. Elif Sertel (TR), Prof. Dr. Nüket Sivri (TR), Prof. Dr. Füsun Balık Şanlı (TR), Prof. Dr. Uğur Şanlı (TR), Duygu Ülker (TR), Prof. Dr. Seyfettin Taş (TR), Assoc. Prof. Dr. Ömer Suat Taşkın (TR), Assist. Prof. Dr. Tuba Ünsal (TR), Dr. Manousos Valyrakis (UK), Dr. İnese Varna (LV), Dr. Petra Visser (NL), Prof. Dr. Selma Ünlü (TR), Assoc. Prof. Dr. Oral Yağcı (TR), Prof. Dr. Murat Yakar (TR), Assoc. Prof. Dr. İ. Noyan Yılmaz (AU); Assit. Prof. Dr. Sibel Zeki (TR)
\end{abstract}




\title{
Analysis of Optimum Growth Stages for Winter Crop Separability using Multi- Temporal NDVI Profiles in Vijapur Taluka, Gujarat State-India
}

\author{
Jayraj B. Panchal $^{1}$ (D), Shital H. Shukla ${ }^{1}$, Manik H. Kalubarme ${ }^{2}$ iD \\ ${ }^{1}$ Gujarat University, School of Sciences, Department of Earth Science, Ahmedabad-India \\ ${ }^{2}$ Ministry of Electronics and Information Technology (MEITY), Bhaskaracharya National Institute for Space Applications and Geo-informatics \\ (BISAG-N), Gandhinagar- India, \\ E-mail: jayrajpanchal10@gmail.com \\ Received: $\quad 01 \quad$ Sept 2020 \\ Accepted: $07 \quad$ Dec 2020
}

How to cite: Panchal, et al. (2021). Analysis of Optimum Growth Stages for Winter Crop Separability using Multi-Temporal NDVI Profiles in Vijapur Taluka, Gujarat State, International Journal of Environment and Geoinformatics (IJEGEO), 8(2):135-143. doi: 10.30897/ijegeo.803303

\begin{abstract}
In the present study analysis of growth stages of different winter crops grown in Vijapur Taluka was carried for determining optimum growth period for crop separability using multi-temporal NDVI profiles. The multi-temporal Sentinel-2 multi-spectral data covering study area for the winter crop period from November-2018 to March-2019 was analysed. The spectral behavior of wheat, cotton, potato, fennel and castor crops during active growth stages was studied and it was observed that the spectral response of these crops is quite distinct. However, wheat and potato have almost matching spectral response during the month of January when wheat was at flag leaf to flowering stage and potato was at maximum vegetative growth stage. This suggests that, single-date Sentinel-2 multispectral digital data of active vegetative growth stages of these two crops during the month of January is not adequate and useful for unique discrimination of wheat and potato. The Normalized Difference Vegetation Index (NDVI) profiles of these major winter crops were generated to monitor and identify the optimum growth stages of the winter crops for their unique separability. The results indicated that, during second fortnight of February, wheat was at grain filling and milk stage and potato was at maximum vegetative stage with tuber maturity and at the same time other crops namely cotton, castor and fennel were at the maturity stages, have quite distinct NDVI values. During the period of second fortnight of February major winter crops with different growth stages had quite distinct spectral behaviour. This indicates that the period of second fortnight of February is quite good and unique for discriminating these winter crops using single date satellite data.
\end{abstract}

Keywords: Winter Crops; SENTINEL-2, NDVI, Crop Growth Stages

\section{Introduction}

Indian agriculture plays very important role in the economy of the country which is influenced by year-toyear variability in monsoon affecting the crop production. The spatio-temporal information about crop growth and its condition is important for monitoring crop progression during the growing season which provides information necessary for efficient crop management. Remote sensing data can be effectively used for providing spatial and temporal information on crop growth and its condition and also for generating crop phenology during growing season. Vegetation indices (VI) computed from satellite images gives an indication of the presence of vegetation and its health. Several studies on remote sensing applications have proved that VI can be used effectively in crop monitoring as well as in characterizing the vegetation with crop phenology. Time series profiles of VI derived from satellite data are potential tools to interpret the dynamics and phenological development of vegetation in different areas.

The advantage of Sentinel-2 multi-temporal data for crop-type classification is very relevant as it reaches up to $91-95 \%$ overall accuracies in various crop classifications (Vuolo, et al., 2018) while single-date images show limited results. The spectral indices computed using Visible and Near Infrared wavelengths are very useful for crop discrimination. The ratio formulation reduces first order bi-directional reflectance and solar zenith induced reflectance variations (Gao, et al., 2002; Sutariya et al., 2021). Normally, parametric Separability Analysis is performed for assess crop separability using the Transformed Divergence (TD). The TD is a commonly used measure that is bounded between values of 0 (no separability) and 2 (completely separable) (Jensen, 1996). It provides a covariance weighted distance between class means to determine whether class signatures are separable. The studies carried out by Boken and Shaykewich, 2002 indicated that the spring wheat yield was found to be best correlated with the average NDVI during the heading phenological phase. The start and the end of the heading phase were estimated using a biometeorological time scale model (Esetlili, et al., 2018).

Time series profiles of vegetation indices derived from satellite data are potential tools to interpret the dynamics and phenological development of vegetation in different areas (Patel and Oza, 2014). Maximum leaf area is achieved 10-15 days before anthesis (flowering stage). 
Labus et al., (2002) have found good relationship between wheat yield and NDVI during the latter part of the growing season, prior to harvest, at the regional scale. Multi-date MODIS data for previous five years provided a-priori information on crop presence / absence over the previous five crop seasons (Rajak et al., 2016). The methodology was to extract key elements of crop growth cycle (i.e., number of crops per year and their planting - peak - harvesting dates) by analyzing MODIS-NDVI data series of one agricultural year (from June 2012 to May 2013) over Gujarat.

\section{Crop Separability using Multi-Temporal Data}

The crop phenological information is used for discriminating crop types, with assumption that the spectral response of different crops might be similar on any single day but the separability among crop types is greatly improved in a multi-temporal space (Palchowdhuri et al., 2018). A method for compositing the multi-temporal NDVI, in order to map winter crop planting areas with the Landsat-7 and -8 and Sentinel-2 optical images was proposed by (Tian et al., 2019). In this study, Landsat 7-8 and Sentinel-2 images were analyzed to increase the frequency of data for mapping winter crops and the results indicated that temporal compositing of minimum and maximum NDVI values at the peak and end of season could mitigate the need for a longer time series of data to discriminate winter crops from forests and spring crops. Time-series curves of vegetation indices are widely used for mapping crops (Cai et.al., 2018), mainly because every crop has a unique phenology during its period of growth (Pan et.al., 2012), and multi-temporal vegetation indices are closely related to crop phenology (Sakamoto et.al., 2012), making them beneficial for improving classification accuracy.

\section{Optimum Crop Growth Stages for Winter crop Separability}

The remote sensing-based crop mapping methods are based on spectral-temporal features. Spectral and temporal features are taken as the major theoretical basis for distinguishing crops from other vegetation, and one crop type from another crop type (Foerster et al., 2012). The mapping methods based on single images have difficulty in identifying two or more crops with similar spectral profiles when the planting situation is complex (Maus, et al, 2016; Ülker et al., 2018). Time-series-based methods make use of the temporal features of crops, and are thus widely used for crop mapping. The study carried out by Meng, et al., 2020 to explore the optimal temporal window for crop mapping using remote sensing data winter wheat and rapeseed. The importance of the diff erent bands for crop mapping was evaluated using the variable importance (VI) index and the results indicated that the combinations of images from the later stages of crop growth were more suitable for crop mapping.

\section{Study Area}

This research was conducted in Vijapur taluka is located at $23.57^{\circ} \mathrm{N} 72.75^{\circ} \mathrm{E}$ in the Maheshana district, the northern part of Gujarat state which is classified as a semi-arid region. The climate is generally dry and hot outside to severely hot from March to June when the maximum temperature stays in the range of 36 to $47^{\circ} \mathrm{C}$ and the minimum in the range of 19 to $27^{\circ} \mathrm{C}$. Rainy season starts from July and ends in September with average annual rainfall is around $750 \mathrm{~mm}$. The major crops grown during Rabi season (winter) are wheat, potato, castor, cotton, and fennel.

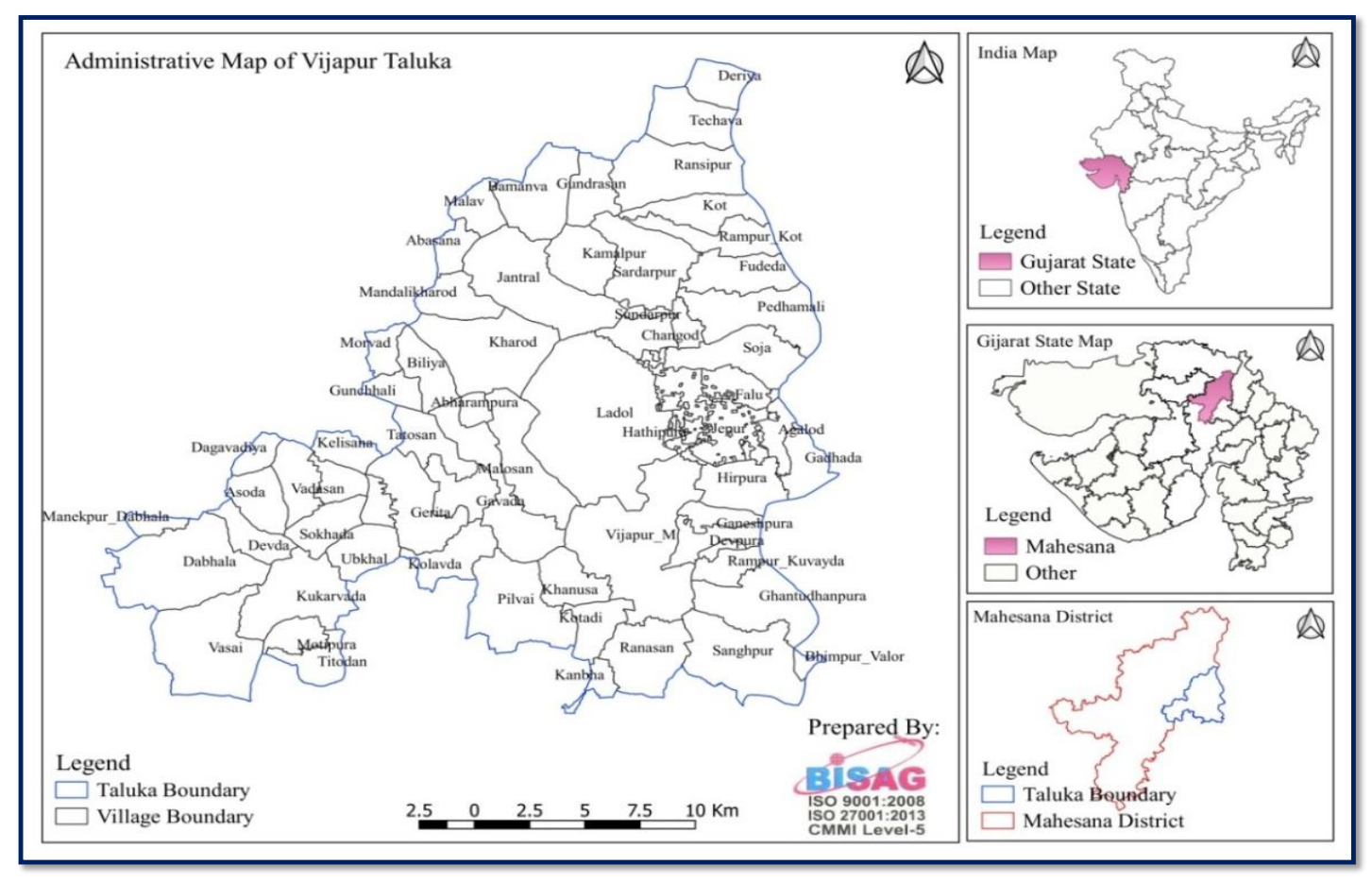

Figure-1: Location map of the Vijapur Taluka in Mahesana district. 
The normal sowing periods for these winter crops in Vijapur taluka as follows: normally wheat is sown middle of November harvested during end of March, potato is grown as winter crop sown in the month of September - October and harvested during FebruaryMarch. The cotton is sown during second fortnight of June and it matures during February - March. The castor and fennel crops are sown during October and harvested at the end of March. This indicates that the growth cycles of these winter crops are slightly different. The location map of the study area of Vijapur Taluka in Mahesana district is given in Figure-1 (Das et al., 2016; Chauhan, et al., 2021).

\section{Methodology \\ Remote Sensing Satellite Data Used}

In this study, multi-temporal Sentinel-2 multi-spectral digital data (spatial resolution 10m) of Rabi season (winter season) from November-2018 to March-2019, a total number of 10-date data covering Vijapur Taluka was downloaded from https://earthexplorer.usgs.gov/. The Sentinel-2 MSI has 13 spectral bands ranging from $0.433 \mu \mathrm{m}$ to $2.19 \mu \mathrm{m}$; four $10 \mathrm{~m}$ visible and nearinfrared bands, six $20 \mathrm{~m}$ red edge, near-infrared (NIR) and short-wave infrared (SWIR) bands, and three $60 \mathrm{~m}$ bands for characterizing aerosols, water vapor and cirrus clouds. Sentinel-2A MSI data are acquired in an approximately $290 \mathrm{~km}$ swath (20.60 field of view from an altitude of $786 \mathrm{~km}$ ) with global coverage every 10 days (Drusch et al., 2012). The Sentinel-2 data products are delivered directly at Top of Atmosphere reflectance values. The Sentinel-2 multi-spectral digital data from Blue (Band-2), Green (Band-3), Red (Band-4), \& NIR (Band-8) of 10-differents dates during growing period of winter crops was acquired in this study. The 10-dates are: i) 04-Nov-2018; ii) 29-Nov-2018, iii) 09-Dec-2019, iv) 24-Dec-2019, v) 03-Jan-2019, vi) 28-Jan-2019, vii) 02-Feb-2019, viii) 17-Feb-2019, ix) 04-Mar-2019 and x) 29-Mar-2019.One of the Sentinel-2 data with Vijapur Taluka boundary is given in Figure-2.

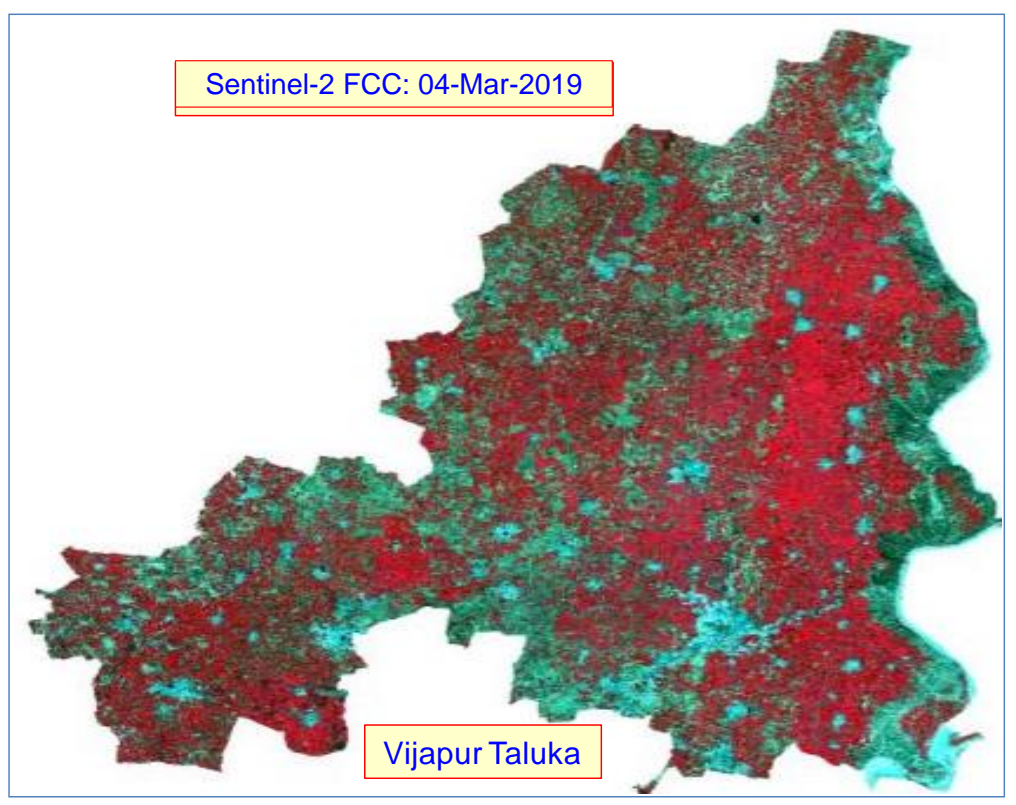

Figure-2: Sentinel-2 multi-spectral image covering Vijapur Taluka.

\section{Field Data Collection}

Ground Truth (GT) data on winter crops grown in different villages of Vijapur Taluka was collected at multiple locations coinciding with different growth stages of winter crops. Five groups of villages having different dominant crops distributed in Vijapur Taluka were selected for field data collection. Large homogeneous sites of wheat and mustard crops with different density classes were identified using the Sentinel-2 False Colour Composite (FCC). The field observations like growth stage and vigour, crop density, size of the field, etc. were recorded for selected sites. The GPS measurements of selected sites along with field photographs were recorded. Some of the field photographs of different winter crops are given in Figure-3.

\section{Remote Sensing Satellite Data Analysis}

The Sentinel-2 multi-spectral and multi-temporal data of winter crop growing season covering study area was analyzed using following major steps:

i) Multi-date data preparation and georeferencing,

ii) Administrative boundary superimposing,

iii) Extraction of area of interest,

iv) Superimposing GPS locations of different crop sites collected during GT data collection on the registered satellite digital data,

v) Identification of different crops on the satellite data and generation of histograms

vi) Generation of Normalized Difference Vegetation Index (NDVI) images and NDVI profiles of different crops. The methodology flow-chart of data analysis is given in Figure-4. 


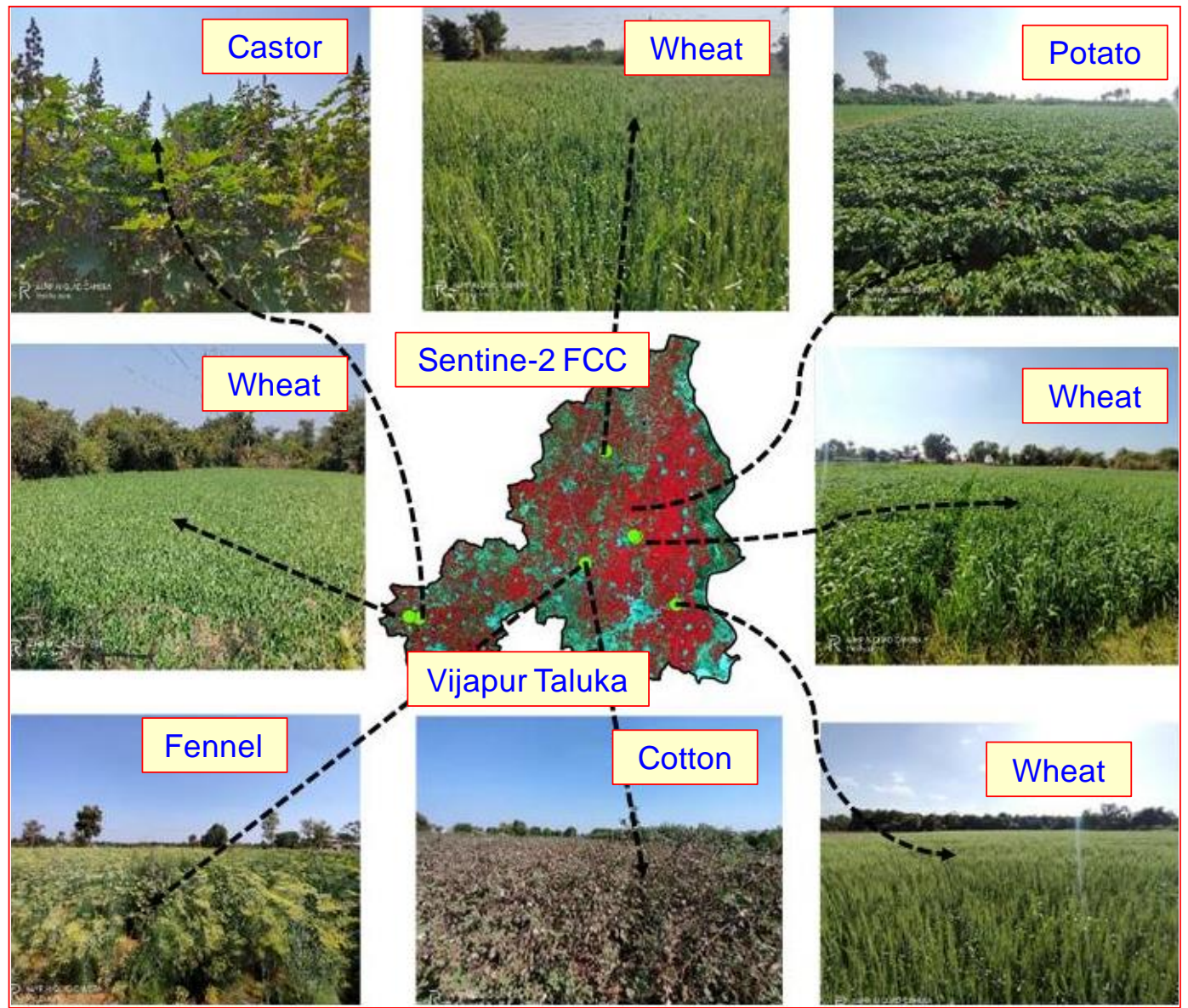

Figure-3: Field Photographs of Major Winter crops in Vijapur Taluka.

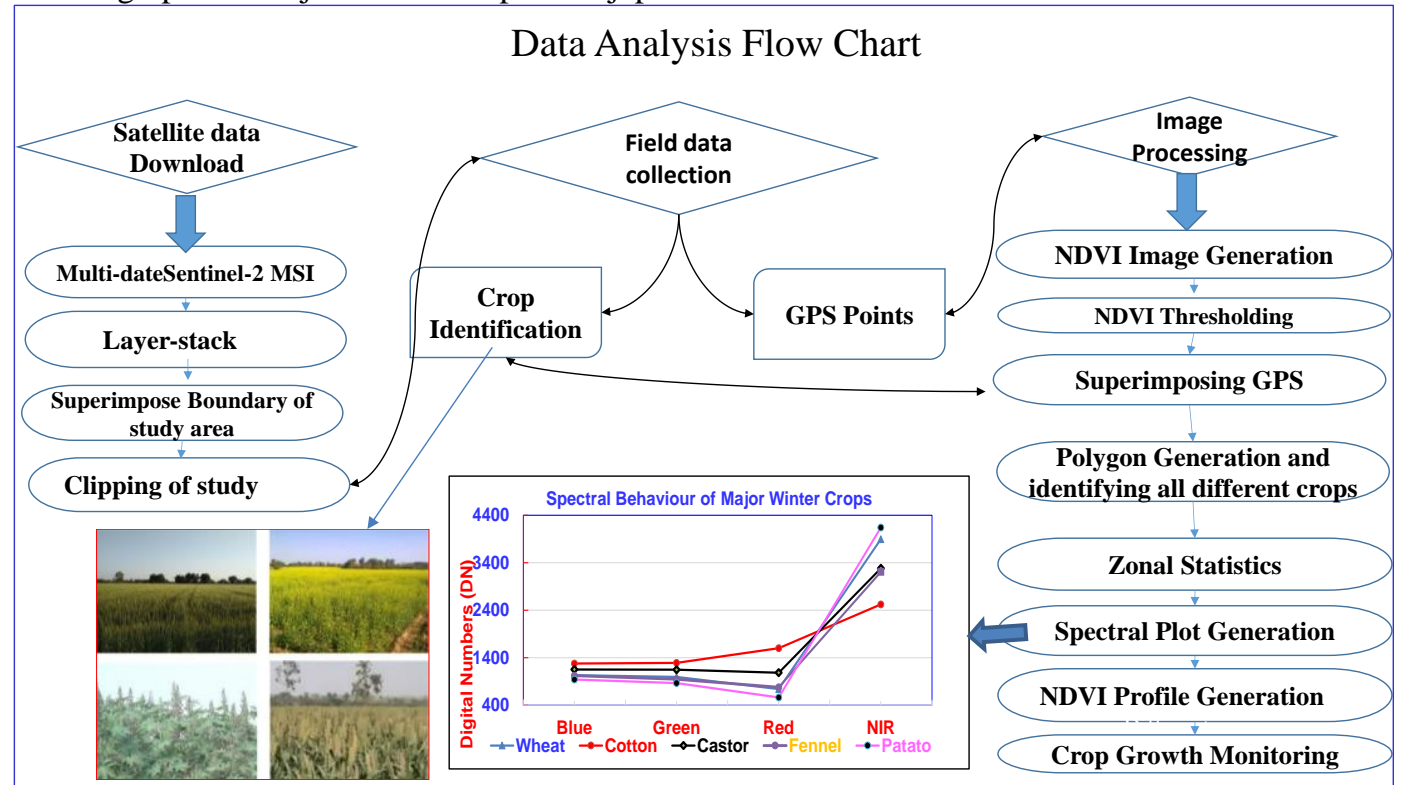

Figure-4: Methodology Flow-chart adopted for data analysis

\section{Multi-date Sentinel-2 Data Analyzed}

The Sentinel-2 multi-spectral digital data from Blue (Band-2), Green (Band-3), Red (Band-4), \& NIR (Band8) of 10-differents dates during growing period of winter crops was analyzed for to study the optimum bio- window for winter crop separability study. The multidate Sentinel-2 satellite data covering study area was extracted using the Taluka boundary and 10-scene analyzed in this study are given in Figure-5 and Figure6. 


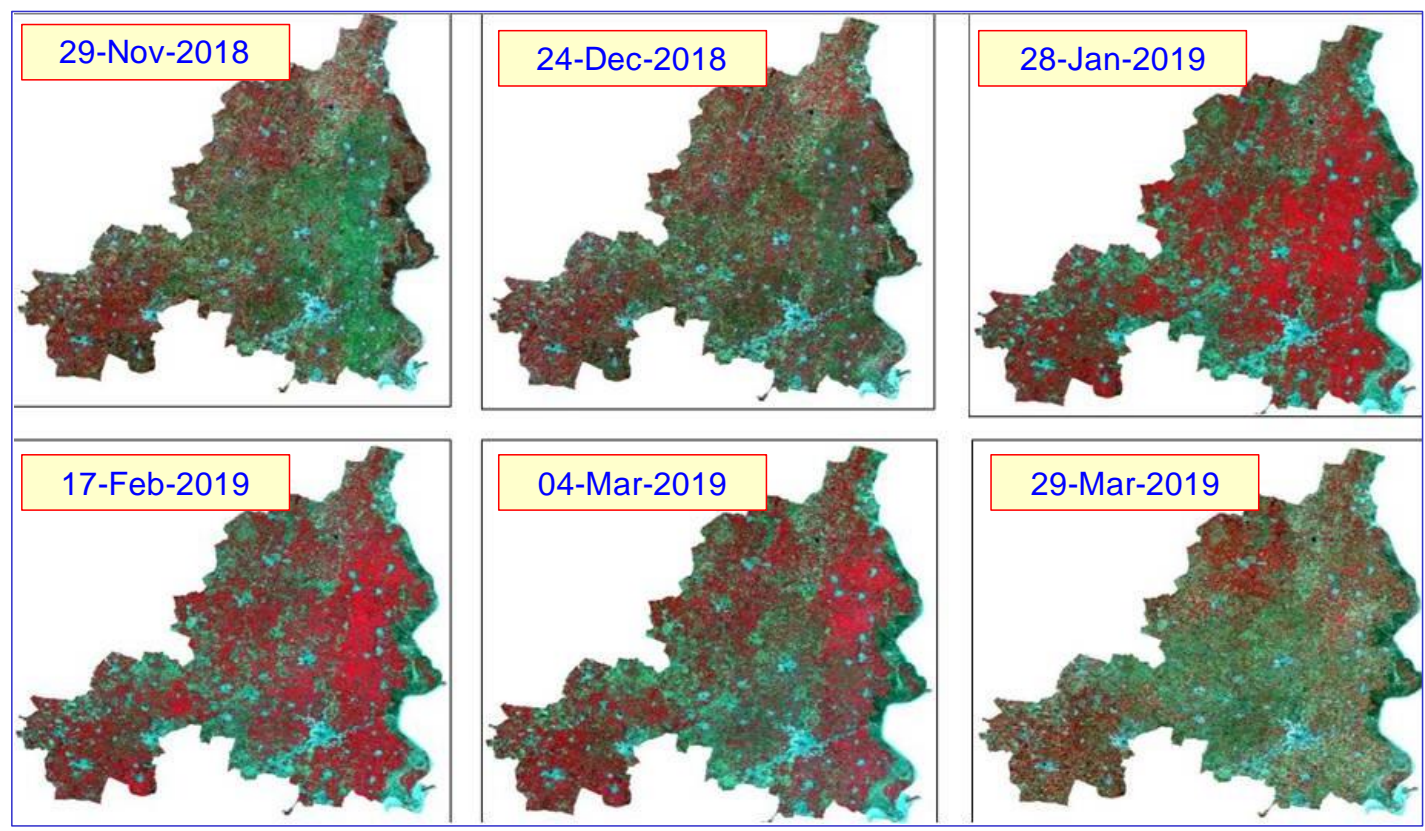

Figure-5: Multi-date Sentinel-2 multi-spectral images covering Vijapur Taluka
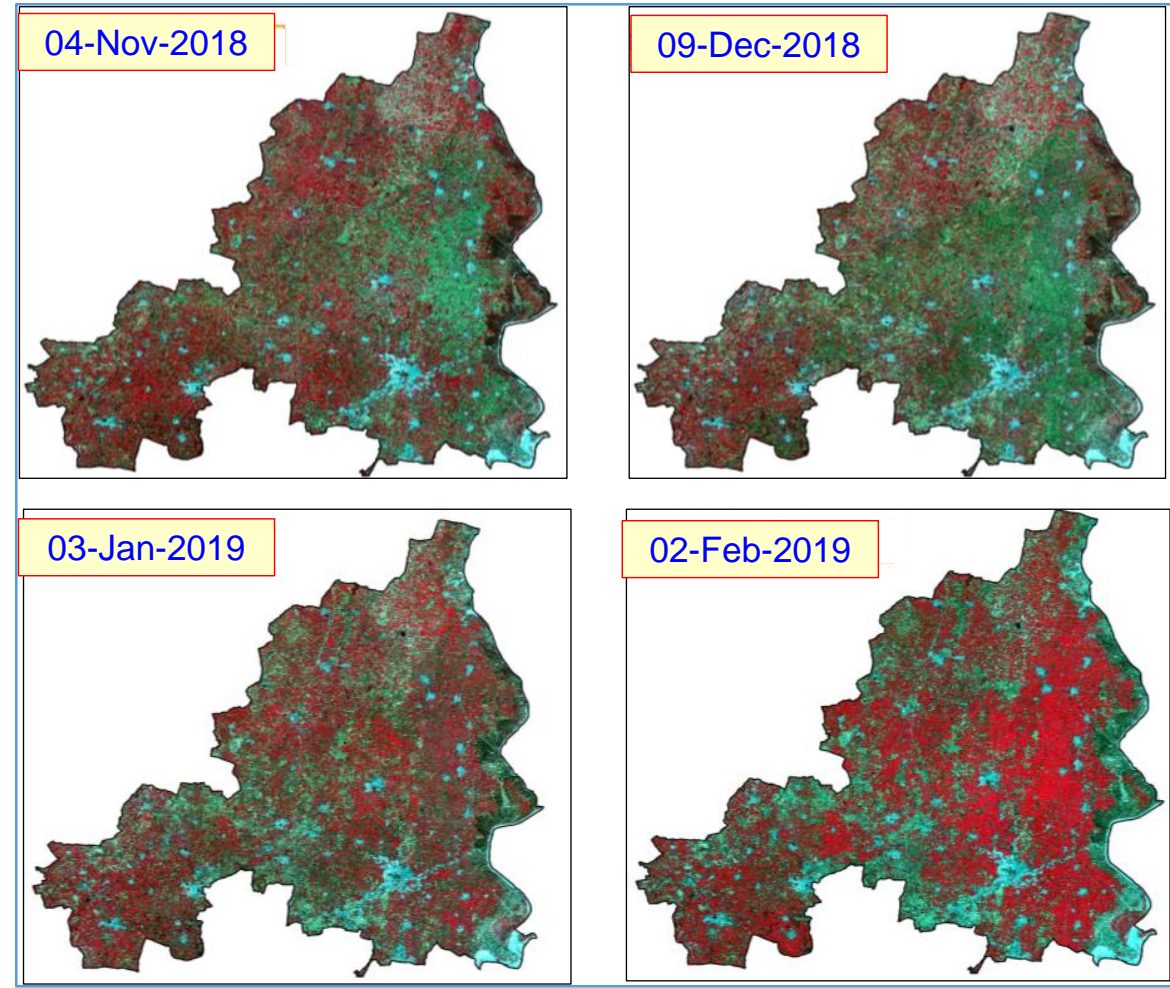

Figure-6: Multi-date Sentinel-2 multi-spectral images covering Vijapur Taluka

\section{Generation of Multi-date Sentinel-2 Data NDVI Images}

Various vegetation indices have been developed for qualitative and quantitative assessment of crop growth and vigour using multi-spectral data. The vegetation indices based on the Visible and Near Infra-Red (VNIR) region such as Normalized Difference Vegetation Index (NDVI) (Tucker, 1979) are highly related to biophysical variables such as leaf area index (LAI) and Normalized Photosynthetically Active Radiation (NPAR) (Baret and Guyot, 1991). The NDVI approach is based on the fact that healthy vegetation has low reflectance in the visible portion of the spectrum due to chlorophyll and absorption by other pigments, and has high reflectance in NIR due to internal reflectance by the green leaf tissue, the values of NDVI ranges from -1 to +1 , where, only positive values correspond to vegetation areas, values close to zero do not mean vegetation, and negative values belong to clouds, snow, water, uncovered soil areas and rocks. The NDVI profiles can be generated over time to study the crop growing conditions throughout the cropping season which can also indicate the crop vigour changes with different phenological stages. The NDVI is computed as follows (Rouse et al. 1973; Mehta et al., 2021):

$$
\mathrm{NDVI}=(\mathrm{NIR}-\mathrm{R}) /(\mathrm{NIR}+\mathrm{R})
$$


Where,

$\mathrm{NIR}=$ reflectance in the near-infrared band, $\mathrm{R}=\quad$ reflectance in the red band
Multi-date NDVI images were generated from the Sentinel-2 multi-spectral data from sowing to maturity stages of winter crops. The NDVI images selected important six-dates are given in Figure-7.

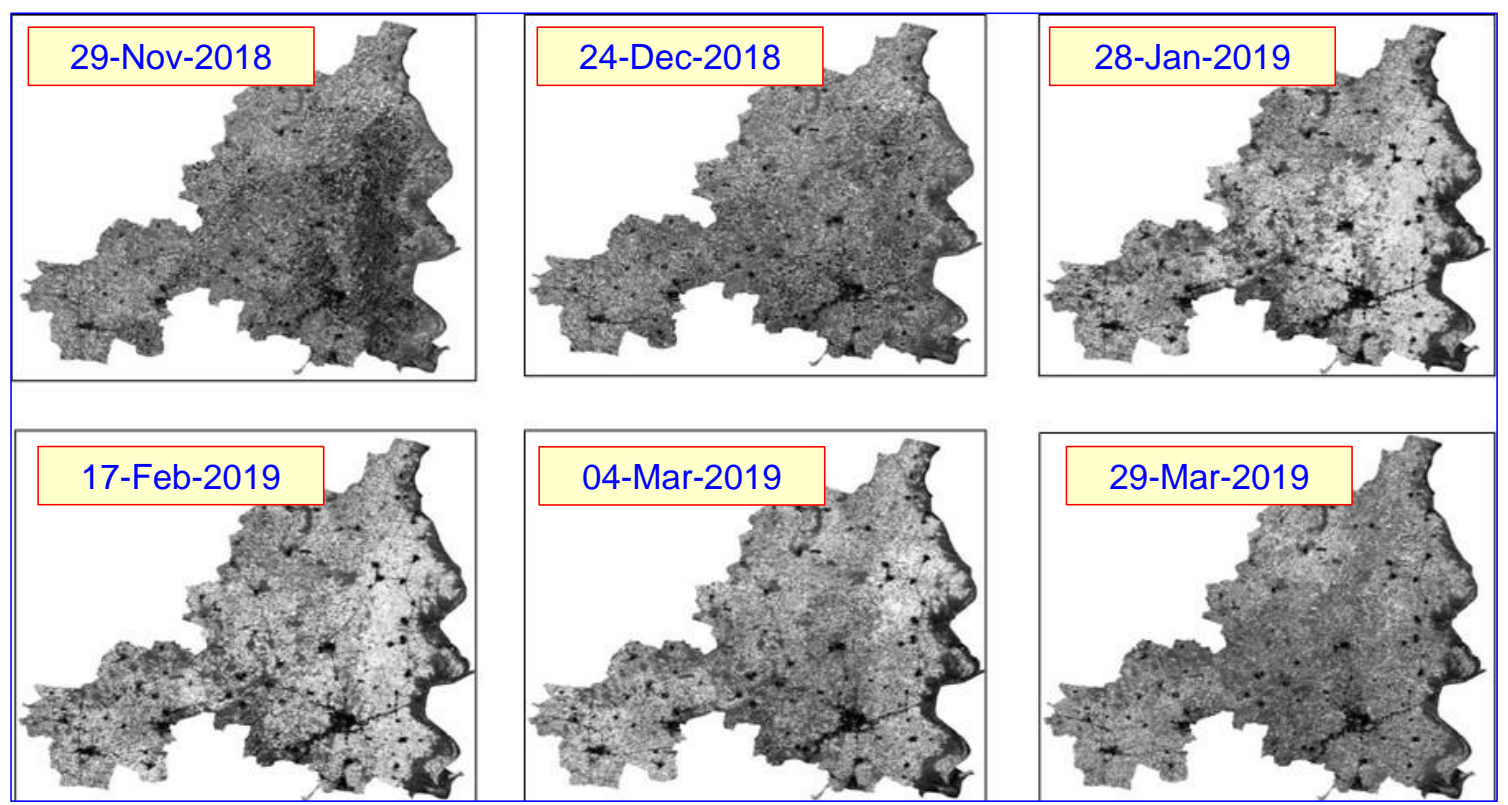

Figure-7: Multi-date NDVI images generated using Sentinel-2 covering Vijapur

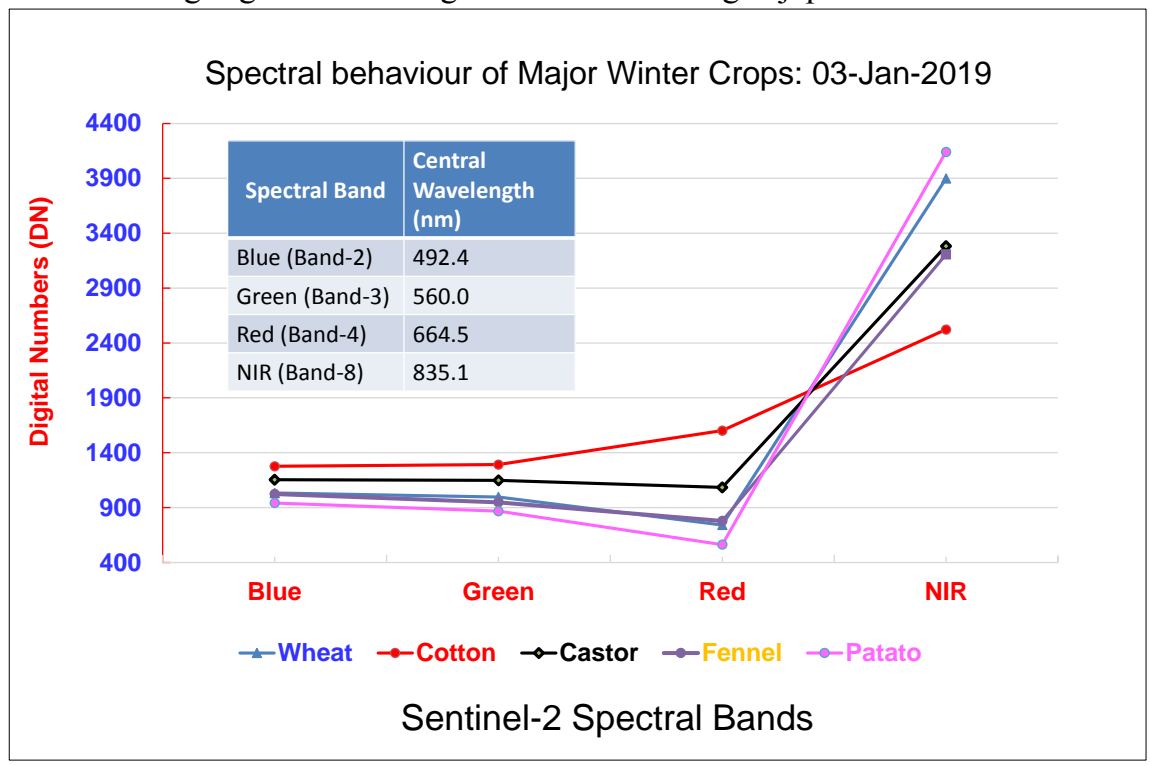

Figure-8: Spectral response of Winter Crops using Sentinel-2 multi-spectral data

\section{Multi-temporal NDVI Growth Profile Generation}

Multi-date NDVI images covering study area were generated for all the 10-date datasets from the Sentinel-2 multi-spectral data from sowing to maturity stages of the winter crops. The GPS measurements were taken in crop fields at different locations and crops were identified on the satellite images using these GPS measurements taken in different fields of wheat, mustard, castor and Fennel crops. The histograms of digital numbers of crop sites were generated using the Multi-temporal NDVI images. The multi-temporal NDVI profiles of these major winter crops grown in different villages of Vijapur Taluka were generated using multi-date Sentinel-2 multispectral data.

\section{Results and Discussion Analysis of Spectral Response of Winter Crops}

The histograms of digital numbers of different winter crop sites identified based on field data at different locations in the selected villages were generated using multi-date Sentnel-2 data. The mean values in each spectral band for winter crops namely, potato, wheat, castor, cotton and fennel were plotted for 03-January2019 where the spectral values of these crops were significantly different (Figure-8). During first week of January these major crops were at active growth stages of flowering and grain filling. The difference in sowing dates of these winter crops results in different 
phenological stages which results in different spectral response of these crops. The phenological stage differences of different winter crops, which results into different spectral reflectance on the satellite data.

It was observed that maximum spectral difference of these winter crops was observed in the NIR spectral band as compared to other visible spectral bands of Sentinel-2 multi-spectral data. The spectral response of wheat, cotton, castor and fennel crops have quite distinct spectral behavior. Cotton crop is almost at maturity stage during the first fortnight of January, it shows quite distinct spectral response as compared to other crops. However, wheat and potato crops do not show distinct spectral behavior during first week of January. This indicates that, during first week of January these two crops have similar vegetative cover which do not to show any spectral differences, so using single date data of January wheat and potato crops cannot be discriminated. Therefore, multi-date data of different growth stages needs to be used for better discrimination of these two crops.

\section{Winter Crop Separability using NDVI Growth Profiles}

In this study, from the NDVI growth profiles generated using 10-date Sentinel-2 data of different crops it was observed that very distinct growth stages like early growth stage to flag leaf emergence which correspondence to rising of NDVI, followed by flag leaf emergence to flowering and grain filling stages which corresponds to maximum NDVI and finally physiological maturity stages corresponding to declining of NDVI of all the winter crops, were observed. NDVI growth profiles (Figure-9) of these winter crops were studied for identifying the different growth stages where maximum variations in NDVI profiles can be observed which can helpful for better crop separability using the spectral data from Remote sensing satellites.

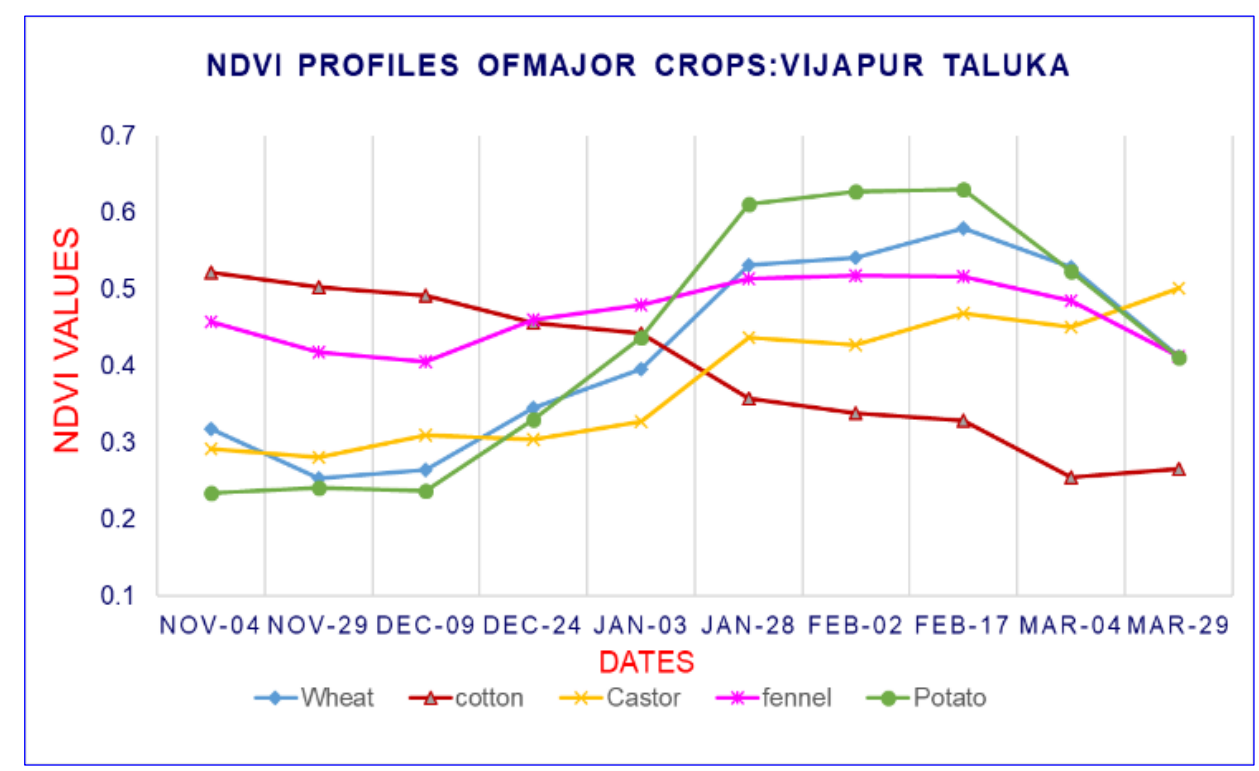

Figure-9: Multi-temporal NDVI profiles of different Winter Crops using Sentinel-2 data

The NDVI growth profiles of these winter crops indicate the temporal variations during different growth stages of the winter crops. The maximum temporal variations can be observed during early growth stages to flowering and grain filling stages. These differences are mainly because of differences in sowing dates resulting in different phonological growth stages.

\section{Optimum Growth Stages for of Winter Crop Separability}

The multi-temporal NDVI profiles of different winter crops (Figure-8) indicate that a single-date temporal image, the distinct discrimination of winter crops may not be posible during the peak growth stage, during first fortnight of Jnuary in the study area. However, during second fortnight of November to first fortnight of December, discrimination of only cotton and Fennel crops which are at maximum vegetative growth stages may be possible. As it can be observed from Figure-7, the best-growth stages which give maximum spectraltemporal separability is during the middle and late growing season which contains more discriminative information for all the winter crops.The NDVI gwoth profile indicates that, the Sentinel-2 data of early growth stages is very helpful for better discrimination of cotton and Fennel crops. However, Satellite data of a later growth stages of all the winter crops during second fortnight of February is very helpful for better winter crop separability. During this period wheat crop is at dough stage, potato at maximum vegetative stage and cotton, castor and fennel are at the maturity stages. These results from NDVI growth profiles explains the suitability of satellite data of middle and late growth stages perform better for winte crop separability.

\section{Conclusions}

This study was carries out with the basic objective of identifying the optimum bio-window for winter crop 
separability using the NDVI growth profiles generated using multi-temporal Sentinel-2 data. The multitemporal Sentinel-2 multi-spectral data (spatial resolution $10-\mathrm{m}$ ) covering study area for the winter crop period from November-2018 to March-2019 (10datasets) was analysed. The resuls of spectral behavior of wheat, cotton, potato, fennel and castor crops during active growth stages indicated that the spectral response of these crops is quite distinct. However, wheat and potato have almost similar spectral response during the month of January when wheat was at flag leaf to flowering stage and potato was at maximum vegetative growth stage. This suggests that, single-date Sentinel-2 multispectral digital data of active vegetative growth stages of these two crops during the month of January is not appropriate and sufficient for unique discrimination of wheat and potato.

The multi-temporal NDVI profiles of different winter crops indicated that using single-date image, the distinct discrimination of winter crops may not be posible with peak growth stages, during first fortnight of January in the study area. The NDVI growth profiles of different winter crops indicated that the best-growth stages which give maximum spectral separability is during the middle and late growing season which contains more discriminative information for all the winter crops. Satellite data of a later growth stages of all the winter crops during second fortnight of February is very helpful for better winter crop separability. During this period wheat crop is at dough stage, potato at maximum vegetative stage and cotton, castor $\&$ fennel are at the maturity stages. These results from NDVI growth profiles explain the suitability of satellite data of middle and late growth stages perform better for winte crop separability.

\section{Acknowledgements}

The authors express their sincere thanks to Director General (DG), Bhaskaracharya National Institute for Space Applications and Geo-informatics (BISAG-N), Ministry of Electronics \& Information Technology (MEITY), Government of India, for his keen interest and encouragement in executing this project.

\section{References}

Boken, V., Shaykewich, C.F. (2002). Improving an Operational Wheat Yield Model using Phenological Phase-based Normalized Difference Vegetation Index, International Journal of Remote Sensing, 23(20):4155-4168

Cai, Y.P.; Guan, K.Y.; Peng, J.; Wang, S.W.; Seifert, C., Wardlow, B.; Li, Z. (2018). A high-performance and in-season classification system of field-level crop types using time-series Landsat data and a machine learning approach. Remote Sens. Environ. 210, 3547.

Chauhan, K., Patel, J., Shukla, S., Kalubarme, M. (2021). Monitoring Water Spread and Aquatic Vegetation using Spectral Indices in Nalsarovar,
Gujarat State-India. International Journal of Environment and Geoinformatics, 8(1), 49-56. doi. 10.30897/ijegeo.790839.

Das, S., Choudhury, M., Gandhi, S., Joshi, V. (2016). Application of Earth Observation Data and Standardized Precipitation Index Based Approach for Meteorological Drought Monitoring, Assessment and Prediction Over Kutch, Gujarat, India. International Journal of Environment and Geoinformatics, 3(2), 24-37. doi. 10.30897/ijegeo.306468.

Esetlili, M , Bektas Balcik, F, Balik Sanli, F, Kalkan, K, Ustuner, M., Goksel, C., Gazioğlu, C., Kurucu, Y. (2018). Comparison of Object and Pixel-Based Classifications For Mapping Crops Using Rapideye Imagery: A Case Study Of Menemen Plain, Turkey. International Journal of Environment and Geoinformatics, 5(2), 231-243. doi. 10.30897/ ijegeo.442002.

Foerster, S.; Kaden, K.; Foerster, M.; Itzerott, S. (2012). Crop type mapping using spectral-temporal profiles and phenological information. Comput. Electron. Agric. 89, 30-40.

Gao, F.; Jin, Y.; Schaaf, C.B.; Strahler, A.H. (2002). Bidirectional NDVI and atmospherically resistant BRDF inversion for vegetation canopy. IEEE Trans. Geosci. Remote Sens. 40, 1269-1278.

Groten S.M.E. (1993). NDVI- monitoring and early yield assessment of Burkina Faso, International Journal of Remote Sensing, 14(8), 1495-1515.

Jensen, J.R. (1996). Introductory Digital Image Processing: A Remote Sensing Perspective, 2nd ed.; Prentice Hall: Upper Saddle River, NJ, USA, 1996.

Labus, M.P., Nielsen, G.A., Lawrence, R.L., Engel, R., Long, D.S. (2002). Wheat Yield Estimates using Multi-temporal NDVI Satellite Imagery, International Journal of Remote Sensing, 23(20): 4169-4180.

Maus, V.; Camara, G.; Cartaxo, R.; Sanchez, A.; Ramos, F.M.; de Queiroz, G.R. (2016). A Time-Weighted Dynamic Time Warping Method for Land-Use and Land-Cover Mapping. IEEE J. Sel. Top. Appl. Earth Obs. Remote Sens. 2016, 9, 3729-3739.

Mehta, D, Shukla, S, Kalubarme, M. (2021). Winter Crop Growth Monitoring using Multi-Temporal NDVI Profiles in Kapadvanj Taluka, Gujarat State. International Journal of Environment and Geoinformatics, 8(1), 33-38. doi. 10.30897/ ijegeo.773860.

Meng, Shiyao, Zhong, Yanfei, Luo, Chang, Hu, Xin, Wang, Xinyu, and Huang, Shengxiang. (2020). Optimal Temporal Window Selection for Winter Wheat and Rapeseed Mapping with Sentinel-2 Images: A Case Study of Zhongxiang in China. Remote Sens. 12, 226; doi: 10.3390/rs12020226.

Palchowdhuri, Y.; Valcarce-Diñeiro, R.; King, P.; Sanabria-Soto, M. (2018). Classification of multitemporal spectral indices for crop type mapping: A case study in Coalville, UK. J. Agric. Sci. 156, 24 36.

Pan, Y.Z.; Li, L.; Zhang, J.S.; Liang, S.L.; Zhu, X.F.; Sulla-Menashe, D. (2012). Winter wheat area estimation from MODIS-EVI time-series data using 
the crop proportion phenology index. Remote Sens. Environ. 119, 232-242.

Patel, J. H., and Oza, M.P (2014). Deriving Crop Calendar using NDVI Time-Series. The International Archives of the Photogrammetry, Remote Sensing and Spatial Information Sciences, Volume XL-8, 2014 ISPRS Technical Commission VIII Symposium, 09 - 12 December 2014, Hyderabad, India.

Quarmby, N.A., Milnes, M., Hindle, T. L., Silleos, N. (1993). The use of multi-temporal NDVI measurements from AVHRR data for crop yield estimation and prediction, International Journal of Remote Sensing, 14(2), 199-210.

Rajak, D., Ram, J., Rajesh K., and Ray, S. S. (2016). Early estimation of crop sown area by integrating multi-source data. Journal of Geomatics, 10(1), 80 88.

Sakamoto, T.; Wardlow, B.D.; Gitelson, A.A.; Verma, S.B.; Suyker, A.E.; Arkebauer, T.J. (2010). A twostep filtering approach for detecting maize and soybean phenology with time-series MODIS data. Remote Sens. Environ 114, 2146-2159

Sutariya, S, Hirapara, A, Meherbanali, M, Tiwari, M, Singh, V, Kalubarme, M. (2021). Soil Moisture Estimation using Sentinel-1 SAR Data and Land Surface Temperature in Panchmahal District, Gujarat State. International Journal of Environment and Geoinformatics, 8(1), 65-77. doi. 10.30897/ ijegeo.777434.

Tian, H.; Huang, N.; Niu, Z.; Qin, Y.; Pei, J.; Wang, J. (2019). Mapping Winter Crops in China with MultiSource Satellite Imagery and Phenology-Based Algorithm. Remote Sens. 11, 820.

Tucker C.J., Elgin J.H., McMurtrey (1980). Relationship of red and photographic infrared spectral data to alfalfa biomass, canopy cover and drought stress, International Journal of Remote Sensing, 1(1), $69-$ 79.

Ülker, D., Ergüven, O., Gazioğlu, C. (2018). Socioeconomic impacts in a Changing Climate: Case Study Syria. International Journal of Environment and Geoinformatics, 5(1), 84-93. doi.10.30897/ ijegeo.406273.

Vuolo, F.; Neuwirth, M.; Immitzer, M.; Atzberger, C.; Ng, W.T. (2018). How much does multi-temporal Sentinel-2 data improve crop type classification? Int. J. Appl. Earth Obs. Geoinf. 72, 122-130. 